Research Journal of Applied Sciences, Engineering and Technology 17(3): 64-73, 2020

DOI: $10.19026 /$ rjaset.17.6043

ISSN: 2040-7459; e-ISSN: 2040-7467

(C) 2020 Maxwell Scientific Publication Corp.

Submitted: November 18, 2019

Accepted: February 25, 2020

Published: June 15, 2020

\title{
Research Article \\ Using Photo Voltage Solar and Light Emitting Diodes to Reduce Energy Consumption: Case Study in Port Sudan City
}

\author{
${ }^{1,2}$ Naeim Farouk, ${ }^{2}$ Mohand Omer, ${ }^{3}$ Samah. G. Babiker and ${ }^{4}$ Mohamed O. Sid-Ahmed \\ ${ }^{1}$ Mechanical Engineering Department, College of Engineering, Prince Sattam bin Abdulaziz University, \\ Saudi Arabia \\ ${ }^{2}$ Mechanical Engineering Department, Faculty of Engineering, Red Sea University, \\ Port Sudan, 33311, Sudan \\ ${ }^{3}$ Physics Department, Faculty of Applied Science, Red Sea University, Port Sudan, 33311, Sudan \\ ${ }^{4}$ Physics Department, Faculty of Sciences, Sudan University of Science and Technology, \\ Khartoum, 11116, Sudan
}

\begin{abstract}
Port Sudan city is a capital of the Red Sea State in the republic of Sudan in south-eastern Africa. The city has high consumption of power for street lighting. The lighting is needed for $12 \mathrm{~h} /$ day. This consumes about 11.5 $\mathrm{Mw}$ day. The aim of this paper is study the proposed system to reduce the streetlight power consumption use in Port Sudan City and to explore the renewable energy to work alternative energy sources. The present paper studies the proposed system called (all-in-one) street lighting system consisting of PV panel, lithium ion battery and light sensor with LED lamp, all connected and constructed in single unit. The proposed system is to be used in Port Sudan city to decrease the electricity consumption, especially in summer. The problem has been treated theoretically. The proposed system has been compared with two types of plant the first plant used 250W lamp Ac and the second plant used 100W LED lamp. The results show that the proposed system has low cost, about 80 USD and much better economically. The proposed system can solve the power loss in Port Sudan city, saving $11.5 \mathrm{Mw}$ day for this city and more than 428,000 SUP/day. The results show that the proposed system could be utilized to reduce lighting consumption, save energy and developments on environment. We therefore recommended to uses the proposed system in many countries not only in Port Sudan City.
\end{abstract}

Keywords: All in one system, modeling of the large PV plant, port Sudan city, power calculation, solar energy, street light

\section{INTRODUCTION}

The green energy from wind, solar, biogas, hydro power and geothermal for world net electricity generation is expected to reach 36.5 trillion $\mathrm{kWh}$ in 2040. Electricity is the world's fastest-growing form of end-use energy consumption, as it has been for many decades (EIA, 2016). Burning fossil fuel to produce electricity contributed about $40 \%$ of $\mathrm{CO}_{2}$ to the environment. There are two ways to reduce these effects: one is to reduce the consumption of the energy and this solution is not applicable, the second is to reduce the pollution by finding alternative energy sources (IEA, 2003). Most of the countries are increasingly using renewable energy for electricity generation. Renewable and biomass technology are proposed to provide an efficient source of energy for electricity. Hydropower, renewable energy, bio power and geothermal energy are clean sources Renewable energy sources are clean, sustainable and environmental friendly. The current energy sources in Sudan are biomass, petroleum and hydropower (Omer, 2005). The best source of energy for lighting in Sudan at the present is hydropower. Although, wind and solar energy are the other suitable sources of energy for lighting. Utilization of these sources of energy for lighting applications will contribute in reducing indoor air pollution (Aghaei and Meisen, 2014).

The electricity load covers the residential sector (homes, schools and governmental buildings), community sector (streetlight and traffics signs) and the industrial sector. In some countries for many reasons as for touristic or safety reasons, the streetlight consumes a high load (Omer, 2002). The goal of this study is to reduce the streetlight power consumption use in Port Sudan City and to explore the renewable energy to work alternative energy sources.

Corresponding Author: Naeim Farouk, Mechanical Engineering Department, College of Engineering, Prince Sattam bin Abdulaziz University, Saudi Arabia

This work is licensed under a Creative Commons Attribution 4.0 International License (URL: http://creativecommons.org/licenses/by/4.0/). 


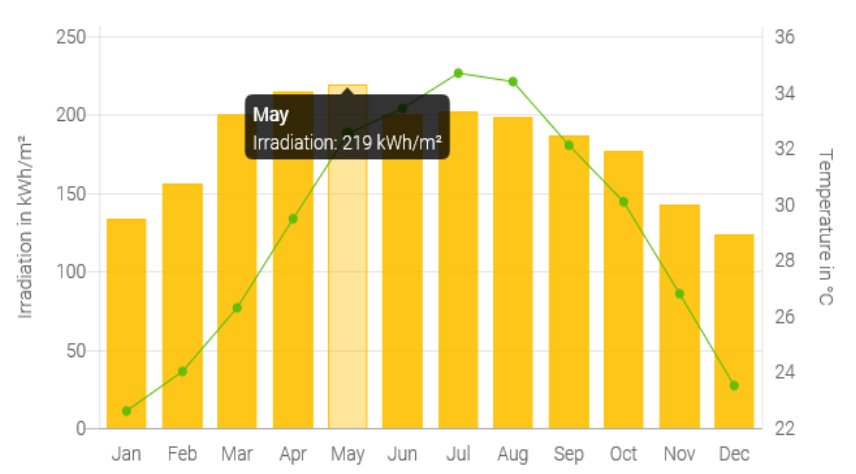

Fig. 1: Port Sudan irradiation (Boyce et al., 2009)

Location: The power output depends on the wind speed, sun radiation and sun's angle. These parameters depend on the location. According to NASA (NASA Agency, https://www.nasa.gov $>$ news $>$ releases >), the sun's rays are $40 \%$ as intense near the poles compared to that near the equator. Figure 1 shows Port Sudan irradiation during 12 months. The highest irradiation is in May, about $219 \mathrm{KWh} / \mathrm{m}^{2}$ and the lowest is in December, $123 \mathrm{KWh} / \mathrm{m}^{2}$ (El Mamoney and Khater, 2004).

Port Sudan: Port Sudan is the capital of the Red Sea State in eastern Sudan. Its location is $\left(19.36526^{\circ} \mathrm{N}\right.$ $37.13292^{\circ} \mathrm{E}$ ) and $13 \mathrm{~m}$ above sea level. The population is estimated to be 579,942 people (Abdel Ati, 2000). Port Sudan climate is the Mediterranean Sea. The high temperature in summer about $48^{\circ} \mathrm{C}$ and in winter ranging from 21 to $30^{\circ} \mathrm{C}$. The national grid supplies the town by electricity which is generates by hydro power and thermal power plants. Port Sudan has about 6000 street lighting lamps. This lamp take power $>8 \mathrm{MW} /$ day from the power provided by national grid by cost about 9000 SUP (Sudanese Pound) daily from the state treasury according to crop of city lighten (NEC, 2014). Port Sudan has high radiation hours about 3200 in year approximately, so we can use solar energy alternative resource for streetlight.

Street light system: Port Sudan city has a simple electric system for lighting the streets; the system contains a pole with total height of about $8 \mathrm{~m}$ and (3035) $\mathrm{m}$ distance between every two poles, with $250 \mathrm{~W}$ nominal power phosphor with mercury lamps with total wire path $38.4 \mathrm{Km}$. In each sector there are number of counters to feed a certain number of poles (NEC, 2014).

Solar energy: Solar energy is divided into two forms Solar Photovoltaic (PV) and solar thermal system. Solar Photovoltaic (PV) system converts sunlight directly into electrical power, whereas solar thermal system utilizes sunlight for heating.

In rural, remote and off-grid areas, solar energy can be used in many applications such as: refrigeration, lighting, heating and cooking (Karekezi and Kithyoma,
2003). Sun shines in Port Sudan in the range of $9 \mathrm{~h} /$ day. Solar radiates on the horizontal surface in the range of $20.87 \mathrm{MJ} / \mathrm{m}^{2} /$ day which is equivalent to insolation in the range of $5.8 \mathrm{kw} \mathrm{h} / \mathrm{m}^{2} /$ day.

Photovoltaic (PV) system consists of PV cells, battery, charger and inverter. The present PV cells are made of silicon crystalline material. The rated power of PV modules for energy applications generally range from several watts to $200 \mathrm{~W}$ (Amogpai, 2007). PV systems can be grid connected or independent off-grid systems. Inverters and batteries are used in different applications in grid connected or off-grid areas. In grid connected system use inverter to convert Direct Current (DC) to Alternating Current (AC). In off-grid PV system can be used in rural, remote areas that lack electricity (Fujii et al., 2013).

Locating the sun's position: The earth is rotating and changing location to the sun, so it is so important to locate the position of the cell according to the source of radiation (sun). In PV system, it is very important to direct the cells in such angle to the horizontal surface that gives the sunlight ability to fall into the module surface for maximum possible duration and intensity. The angle at which the module is inclined is called tilt angle (Bajpai et al., 2010). To determine the optimum tilt angle, it will be necessary to locate the position of the sun from the given site on the earth:

$$
\begin{aligned}
& \text { Declination angle of sun }=23.45 * \sin [360 * \\
& \left.\frac{(284 * \mathrm{~N})}{365}\right]
\end{aligned}
$$

where,

$\mathrm{N}$ : The day number in the year $(\mathrm{N}=1$ for January 1 and $\mathrm{N}=365$ for December 31 )

By using the equation above, the optimal array tilt angle can be determined for monthly adjustments, or for adjustments any time.

\section{LITERATURE REVIEW}

Using of solar energy in street light: In 2011 Electrical division MSME - Development institute, 
ministry of MSME, government of India contract a street light system in Agra city. The system is provided with battery storage backup sufficient to operate the light for 10-11 h daily. This system was provided with automatic on/off time switch for dusk to dawn operation and overcharge/deep discharge prevention cut-off with LED indicators (Panjang and Ulu, 2015).

In 2015 another team from Brunei National Energy Research Institute, constructed an off-grid PV lighting system (Panjang and Ulu, 2015).

In 11 may 2015 Kumar and Sudhakar (2015) published a paper about the performance of PV plant which produces about $10 \mathrm{Mw}$ at location has nearly $3000 \mathrm{~h}$ of sun radiation and 50 acres $\left(0.2 \mathrm{~km}^{2}\right)$ of land. This plant is divided to eight areas or blockers with each two equal blocks. Each individual block has the generating capacity of about $625 \mathrm{Kw}$ thus total of sixteen blocks combined to form a $10 \mathrm{Mw}$ generation capacity. Each block of solar panels consists of about 230 strings each and a total of 1852 strings These large numbers of solar panels in single block are again divided into two blocks of strings. Each string consists of 24 solar panels connected in series and about 120 of these strings are connected in parallel to a single inverter through a main string combined box, every string have 24 module.

\section{RESULTS AND DISCUSSION}

Modeling of the large PV plant: For designing Photovoltaic array or plant (PV system), we must calculate the energy consumed by the load in one day. The first step is to prepare a table of daily consumption of electrical energy by the applications to be powered by PV system.

The DC loads should be preferred over Ah loads to minimize the cost, no inverters cost, the energy loss and increase the system reliability.

The mathematical expression for the load calculation is:

$$
\text { Total average DC W h per day }=\frac{\text { Total load }}{7}
$$

Table 1 shows load system which used for all sectors in city, which calculated by division the total average DC over the system voltage (Vs).

In Port Sudan the street light system has more than 3,800 lamps and growing. Those lamps consume more than $11500 \mathrm{Kw}$ day throughout $12 \mathrm{~h}$ day.

This daily load consumes about $4197500 \mathrm{Kw}$ (4.198 Gw year). This system like any system has different losses (wiring system, cap asters, inverters...), with a growing rate of many factors such as demographic and domestic tourism and also security factors. If, we assumption increasing of lamps is 600 lamps in all sectors for 2 years. The total of consuming will be nearly $13,300 \mathrm{Kw}$ day in next 2 years; with an
Table 1: An ampere hour or Ah loads for used system

\begin{tabular}{llll}
\hline Sector & Total poles & No. of lamps & Consume Kw day \\
\hline Eastern & 627 & 1,062 & 3,186 \\
Middle & 1,092 & 1,200 & 3,600 \\
Southern & 883 & 1,560 & 4,680 \\
Total & 2602 & 3,822 & 11,466 \\
\hline
\end{tabular}

E Consume per Kw day using 250 w lamp

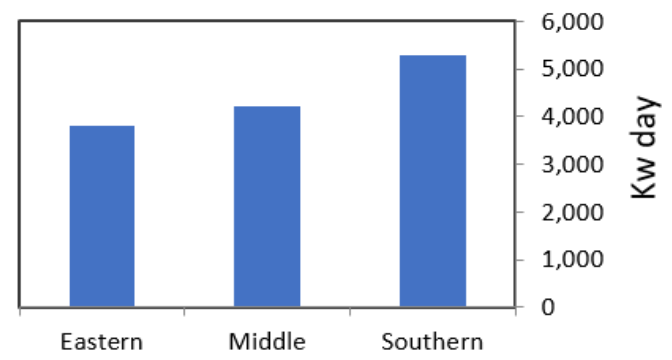

Fig. 2: Consumption of all sectors with 250W lamp

assumption the system losses are $15 \%$ the $15,295 \mathrm{Kw}$ day and about 1,275 kWh.

Sizing of module/array: The important factor in the modeling is number of the modules which must be constructed and installed in the PV power plant $\left(\mathrm{N}_{\mathrm{i}}\right)$. Number of modules is counted according to the PV power plant rating (Pplant, num) in (W) divided to power of module (PM):

$$
\begin{aligned}
& N_{i 0}=\left(P_{\text {plant }, \text { num }}\right) \text { in }(W) / \mathrm{PM} \\
& N_{i 0}=\frac{1,275,000}{345}=3696 \text { module (pre }- \text { sizing) }
\end{aligned}
$$

There is many types of solar photovoltaic modules and cells, one of these modules is mono-crystalline, which generate 345 wh and this type can be suggested to be used in the proposed system. The number of modules can be calculated by using Eq. (4) as shown in Table 2 (multiply the number of module in factor 1.3 efficiency and growth rate is 1.2.

Figure 2 shows the calculation of consumption of all Sectors with 250W lamp:

$$
\text { NUM module }=\frac{\text { Consume per } \mathrm{kWh} * 1.3}{\text { Module } \mathrm{PW}}
$$

Figure 3 shows power sectors consummation details which obtaining from electricity ministry. The number of modules, the sizing of the battery and invertors, was changed in the calculation method.

Power calculation: The lamp was used in Port Sudan street light system lucalox-standard-tubular using mercury Content $16.434 \mathrm{mg}$ and Light Center Length $158 \mathrm{~mm}$ from TUNGSRAMTM company made in 


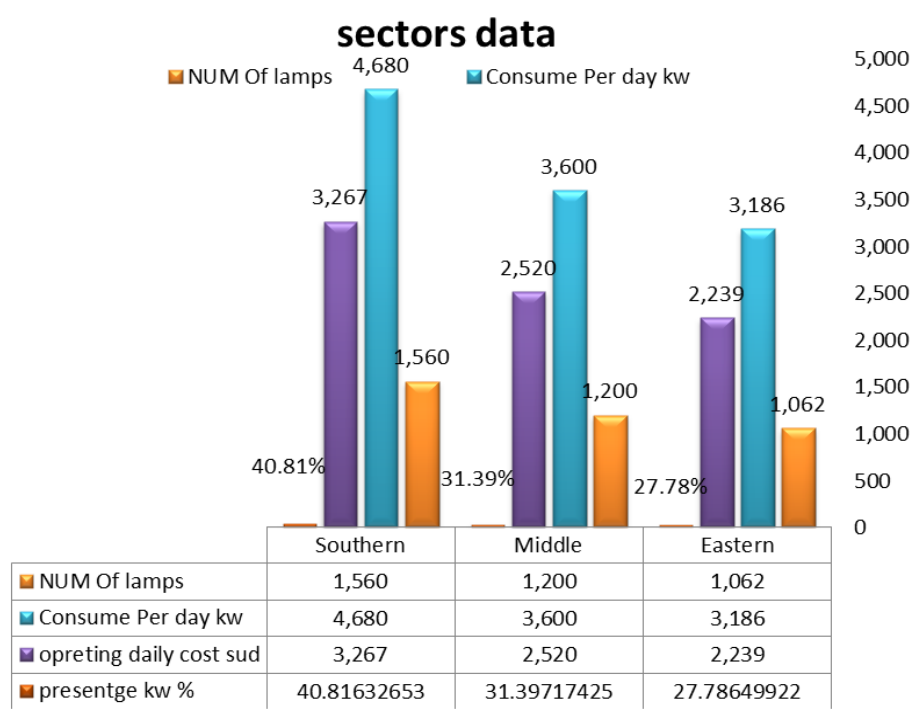

Fig. 3: The power sectors consummation details

Table 2: PV modules need for each sector

\begin{tabular}{lllll}
\hline Sector & No. of lamps & Consume/Kwh & Factor 1.3 & Consume Kw day \\
\hline Eastern & 1,262 & 316 & 411 & No. of module \\
Middle & 1,400 & 350 & 449 & 1,190 \\
Southern & 1,760 & 440 & 572 & 4,792 \\
Total & 4,422 & 1,106 & 1,462 & 5,280 \\
\hline
\end{tabular}

Table 3: Panel data

Nominal power $\mathrm{W}$

Open circuit voltage A

Voltage at max power $\mathrm{V}_{\mathrm{MP}}$

Current at max power $\mathrm{A}_{\mathrm{MP}}$

Operating temp. $\left({ }^{\circ} \mathrm{C}\right)$

Dimensions $(\mathrm{L} \times \mathrm{W} \times \mathrm{H}, \mathrm{mm})$

Weight $(\mathrm{Kg})$

Price

\begin{tabular}{lll}
\multicolumn{2}{l}{ Table 4: Mechanical specifications } & \\
\hline Length (A) & $471.5 \mathrm{~mm}$ & $18.5 \mathrm{in}$ \\
Width (B) & $347.5 \mathrm{~mm}$ & $13.7 \mathrm{in}$ \\
Height (C) & $375 \mathrm{~mm}$ & $14.7 \mathrm{in}$ \\
Weight & $87 \mathrm{~kg}$ & $192 \mathrm{lb}$ \\
Terminal & M8 & \\
Terminal torque & $6.64 \mathrm{ft}-1 \mathrm{~b}$ & $9 \mathrm{Nm}+/-3$ \\
Case material & Steel & \\
IR rating & IP 55 & \\
\hline
\end{tabular}

Hungary. This type of lamp exported since the system established in the beginning of the $21^{\text {st }}$ Century (Christian and Lestari, 2017).

\section{The eastern load and sizing calculations:}

Load calculations: The total power is calculated by multiplying the total nominal power for the total lamps:

$$
250 \times 1262 \text { lamp }=315.5 \mathrm{Kw}
$$

The total energy given by multiplies the total power consumed by the system to the operating hours which is $(12 \mathrm{~h})$ :

Total energy $=3786 \mathrm{Kwh}$
In the proposed system mono-crystalline panel is used because of its high efficiency and high-power output, from AE solar German company. The panel data as shows in Table 3.

The total voltage and total current calculations at max power for the proposed system in eastern sector (as example):

Single module $\mathrm{V}_{\mathrm{MP}} \times$ number of modules in series $39.34 \times 4=157.36 \mathrm{~V}$

Ampere $=$ system power $/$ voltage $=411 / 157.36=$ $2.612 \mathrm{~A}$

Number of modules in parallel can be found by dividing the current of the system to the IMP:

$2612 \mathrm{~A} / 8.77=298$ module in parallel

To make sure that our calculations is right we multiply the number of modules in series and number of the module in parallel:

$$
298 \times 4=1190 \text { module }
$$

Sizing of the battery: The best type of batteries for large PV solar system off grid is lithium ion (AES). This is because of high Depth of Discharge (DOD), high efficiency, long life (up to 15 years in $65 \%$ DOD), fast Charging $15 \%$ more than lead acid batteries and zero maintenance cost. The lithium battery has 10 years warranty with 7,300 USD price for each battery (Doughty and Roth, 2012). Table 4 and 5 shows the 
Table 5: Electrical specifications

\begin{tabular}{ll}
\hline Nominal voltage & $51.2 \mathrm{~V}$ \\
Charge voltage & $54.4 \mathrm{~V}$ \\
Maximum voltage* & $58.4 \mathrm{~V}$ \\
Minimum voltage & $44.8 \mathrm{~V}$ \\
Nominal capacity (IC) & $130 \mathrm{Ah}$ \\
Nominal energy (IC) & $6656 \mathrm{Wh}$ \\
Max. continuous current & $130 \mathrm{Adc}$ \\
Peak current & $300 \mathrm{Adc}(3 \mathrm{sec})$ \\
\hline
\end{tabular}

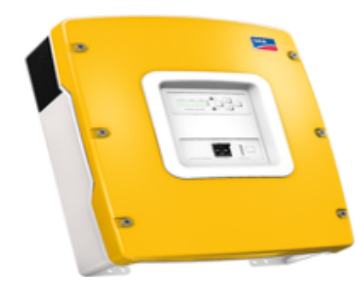

Fig. 4: The proposed inverter (sunny island inverter)

mechanical and electrical specification of the proposed battery.

Battery capacity sizing for eastern sector: The results were show in Table 2 the total load per Kw day is 3,792 $\mathrm{Kw}$ day for 1,262 lamps with $250 \mathrm{~W}$ nominal power. The calculations will be different according to type of the batteries:

The battery capacity calculation $=$ Power $(\mathrm{kW} /$ day) $\times \mathrm{EF}_{\mathrm{f}} \times \mathrm{DOD}_{\mathrm{f}} \times \mathrm{CR}_{\mathrm{f}} \times \mathrm{T}_{\mathrm{f}}$

$3792 \times 1.05 \times 1.25 \times 1.05 \times 1.08$

$=5644 \mathrm{Kw}$ day

Anatomy and sizing of battery: The battery capacity has been calculated by dividing the total power consumed per day. The battery capacity over $48 \mathrm{~V}$ battery voltage multiplies (24) batteries in series (assumed) we will get $4900 \mathrm{amp} / \mathrm{h}$. The dividing the system ampere hours to the maximum current of individual battery, this will give the number of batteries in parallel (38).

The total number of batteries is (912) battery, every individual battery has $6656 \mathrm{~W} / \mathrm{h}$ nominal energy. To make sure that the total batteries will cover the total energy of the system we can multiply the total number of batteries to the nominal energy of individual battery that give us $(6,070,272 \mathrm{wh})$ which is little bigger than the total energy needed $(5,644,000 \mathrm{wh})$ approximately, if we change the number of batteries in parallel to 36 battery the calculation will be $(36 \times 24 \times 6,656)$ and giving about $(5,750,784 \mathrm{wh})$ and that is enough.

Sizing of inverter: Photovoltage grid connected system use inverter to convert Direct Current (DC) to Alternating Current (AC). The inverter sizing depends on many factors such as power output from array and the rate of discharge of storage system. For the proposed system, can use DC lamp and Dispense from inverter, that means less structure and initial cost.

The simulation method (PV*SOL premium 2019 software version online simulation) has been suggested an inventor type called (Active energy storage $\mathrm{GmbH}$ inverter) and sized a 17 inverter for eastern sector. For the proposed system we suggested another inverter cheaper with high capacity and high warranty call (sunny island 4548-US) as shows in Fig. 4.

The sizing of Charge Regulator (CR): The Charge Regulator (CR) normally is used to protect the battery against over charge or deep discharge also to transfer the maximum available power from the PV array. By using another simulation program designed by ATLE Company, the eastern sector solar plant needs about $32517 \mathrm{amp} h$ charge regulators with the number of 1131 solar panels.

For regulating the power from the panels to batteries with this load specification, Table 6 , the suggested CR is 200 amps called Deming MPPT as shown in Fig. 5.

We need about $162 \mathrm{CR}$ for the eastern region.

Table 7 shows the quantities of main items in PV plant of all sectors and the approximated sizing.

The proposed street lighting system: Street lighting in any country follows certain standard. The European standard sets different lighting classes as a set of photometric requirements for different visual needs. The common street lighting classes according to this standard are ME, CE, S, A, ES and EV. The common light sources are categorized into incandescent lamps, fluorescent lamps, High Intensity Discharge (HID) lamps and Solid-State lamps (Amogpai, 2007).

The street lighting system load depends in general on the single lamp capacity. In Port Sudan the lamp which is used is phosphor type. It consumes about $3,000 \mathrm{~W} /$ day and the life time also is not preferable for working $12 \mathrm{~h} /$ day.

Table 6: CR specification

\begin{tabular}{|c|c|c|c|}
\hline \multicolumn{4}{|l|}{ Quick details } \\
\hline Place of origin & Shandong (China) & Brand name & Deming \\
\hline Model of number & SCDC-48V200A & Rated voltage & $48 \mathrm{~V} 96 \mathrm{~V} 192 \mathrm{~V} 220 \mathrm{~V} 240 \mathrm{~V} 360 \mathrm{~V} 380 \mathrm{~V} 480 \mathrm{~V}$ \\
\hline Maximum current & $200 \mathrm{~A}$ & Application & Solar system controller \\
\hline Product name & $\begin{array}{l}\text { MPPT solar charge controller } \\
\text { price for solar mppt power }\end{array}$ & Charge mode & MPPT maximum power point tracking \\
\hline Warranty & 1 year & Display & Display working status \\
\hline System voltage & $48 \mathrm{~V}$ & Rated current & $30 \mathrm{~A} / 40 \mathrm{~A} / 50 \mathrm{~A} / 60 \mathrm{~A} / 70 \mathrm{~A} / 80 \mathrm{~A} / 100 \mathrm{~A} / 200 \mathrm{~A}$ \\
\hline Type & $\begin{array}{l}3 \text { stages mppt solar charge } \\
\text { controller }\end{array}$ & & \\
\hline
\end{tabular}




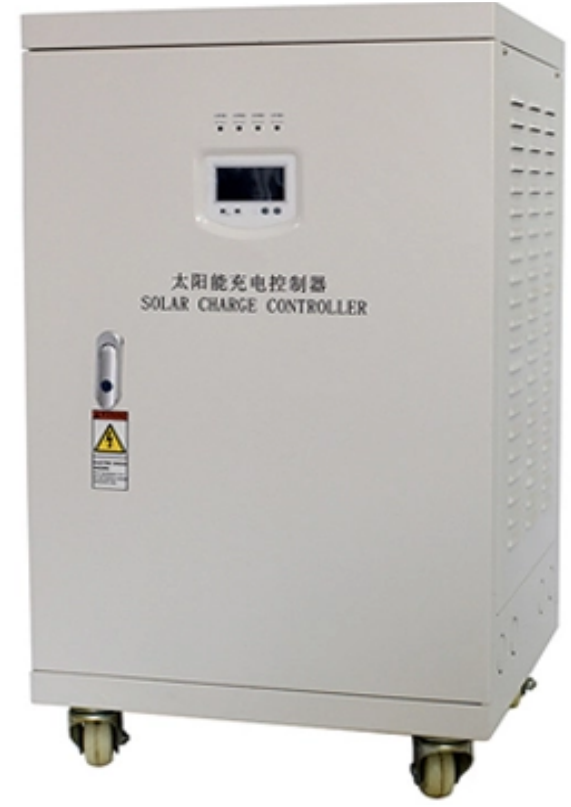

Fig. 5: CR deming MPPT

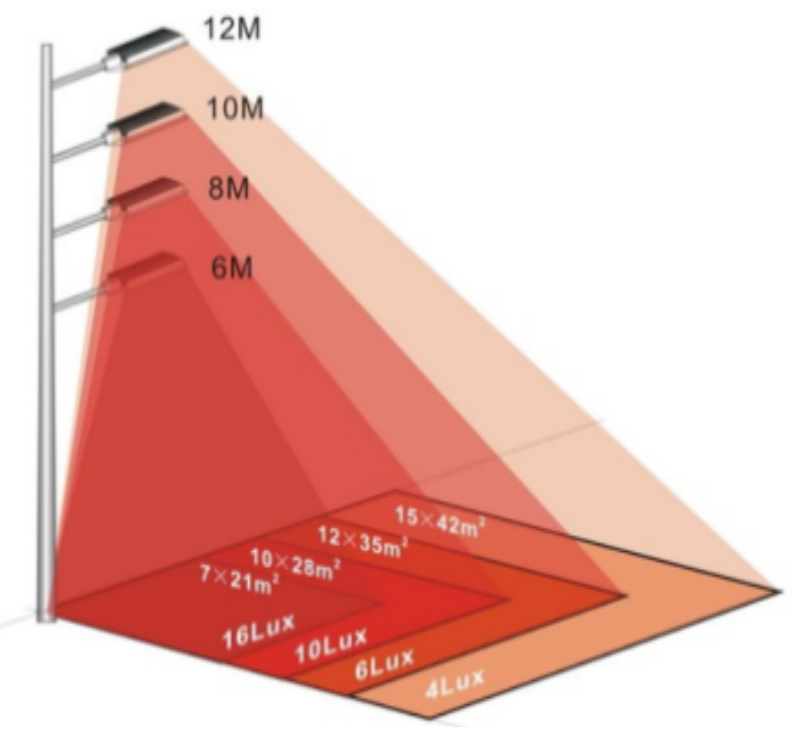

Fig. 6: Pole height and area relationship for Lux

Table 7: The quantities of main items in PV plant of all sectors

\begin{tabular}{lllll}
\hline Sector & $\begin{array}{l}\text { No. of } \\
\text { modules }\end{array}$ & $\begin{array}{l}\text { Number of } \\
\text { batteries }\end{array}$ & $\begin{array}{l}\text { Number of } \\
\text { inverter }\end{array}$ & $\begin{array}{l}\text { Number of } \\
\text { CRs }\end{array}$ \\
\hline Eastern & 1,190 & 912 & 22 & 164 \\
Middle & 1,300 & 999 & 22 & 164 \\
Southern & 1,658 & 1,277 & 24 & 166 \\
\hline
\end{tabular}

In these days, the factors, performance and low cost of High-Brightness (HB) LEDs will open a way for general lighting markets. LEDs have a good life time of range 100,000-50,000 $\mathrm{h}$ and burring life, about $(4,166$, 7 day) or (11.44 years).

According to the EU street light specifications, which worked according to EU specifications in Alzbadani city in Syria, the system in Port Sudan matches the street light criteria, with pole height $(8 \mathrm{~m})$ and distance between two poles about (25-35) $\mathrm{m}$.

With pole specifications $(9 \mathrm{~m}$ high and $35 \mathrm{~m}$ distance between two poles), a $80 \mathrm{~W}$ LED used in 234 light unit with 9,600 Luminous in alzabdani city. With caution the system in Port Sudan using 28750 Luminous Hg-lamps with $251.6 \mathrm{~W}$ according to the manufacturing electrical sheet data, the luminous it's too much comparing with the EU standers. Table 8 shows the comparison of different lamps types and LED.

Figure 6 shows the relationship between pole height and covered area with the lux of the specific 
Res. J. App. Sci. Eng. Technol., 17(3): 64-73, 2020

Table 8: Comparison of different lamps types and LED

\begin{tabular}{llll}
\hline Specifications & LED & High Pressure Sodium Vapor (HPSV) & High pressure mercury vapor \\
\hline Distance between poles & 30 & 30 & 30 \\
Number of poles & 33 & 33 & 33 \\
Investment $(\$)$ & $\$ \$ \$$ & $\$ \$$ & $\$$ \\
Lamp wattage & $70 \mathrm{w}$ & $150 \mathrm{w}$ & $250 \mathrm{w}$ \\
System wattage & $70 \mathrm{~W}$ & $180 \mathrm{w}$ & $300 \mathrm{~W}$ \\
Luminous efficiency & $90-130 \mathrm{Lm} / \mathrm{W}$ & $100 \mathrm{Lm} / \mathrm{W}$ & $60 \mathrm{Lm} / \mathrm{W}$ \\
System efficiency & Rapidly improving) & $80 \mathrm{Lm} / \mathrm{W}$ & $48 \mathrm{Lm} / \mathrm{W}$ \\
Watt per square meter & 0.33 & 0.86 & 1.42 \\
Lifetime & $50 \mathrm{k} \mathrm{h}$ & $12 \mathrm{k} \mathrm{h}$ & $5 \mathrm{k} \mathrm{h}$ \\
Annual energy consumption & $\$ 1532$ & $\$ 3938$ & $\$ 6563$ \\
Hazardous substances & No & Yes & Yes \\
Color Rendering Index (CRI) & $>70$ & 25 & $<60$ \\
\hline
\end{tabular}

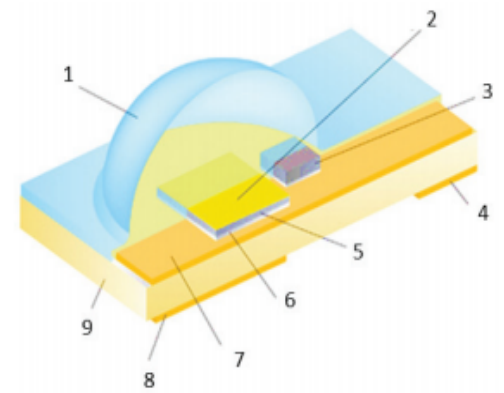

Fig. 7: LED structure

Table 9: LED lamp data

\begin{tabular}{ll}
\hline Name & LED street light \\
\hline Luminous & 10.000 \\
Burning life & $50000 \mathrm{~h}$ \\
Nominal power & $100 \mathrm{w}$ \\
Origen place & Jiangsu-China \\
Company & Town light \\
Current & DC \\
\hline
\end{tabular}

lamp according to EU standards for street lighting in 2004 (Christian and Lestari, 2017).

LED lamp: The Light-Emitting Diodes (LED) are diodes which emit white light. They are digital light based on the same technology as computer small chips.

LEDs have significant advantages over incandescent lamps such as: long life time, less energy consumption, high luminous efficacy, high consistency of color, no movable parts, also have low heat emitting and work under high temperatures nearly up to $80^{\circ} \mathrm{C}$ (Boyce et al., 2009).

In the street lighting lamp structure, the manufacturers put a group of diodes light to get the specific luminous with low watt consumption. Figure 7 shows the LED lamp element structure which is suggested to be used in Port Sudan street lighting. It consists of:

- $\quad$ Silicone lens

- Phosphor plate

- Transient voltage suppressor

- Cathode

- LED chip
- Bond layer

- Metal interconnect layer

- Thermal bed

- Ceramic substrate

We proposed LED lamp which has 10,000 luminous and long burning life up to $50,000 \mathrm{~h}$ of lighting and DC current, to be a replacement to $250 \mathrm{~W}$ lamp in Port Sudan street light system. It is made by Town light company with 5 years warranty from the company as shown in Fig. 8. Table 9 shows the LED lamp data.

Load calculation and module sizing: When we replace the lucalox-standard-tubular, which used in Port Sudan street light system who consumes about $250 \mathrm{~W}$ nominal power and use LED lamp with nominal power $100 \mathrm{w}$; this will reduce the load calculation rate to about 0.4 .

The load calculation rate, number of solar module and batteries number are decreased, because using DC current that means no inverter is needed. The change in sizing details lead to minimizing the initial cost. The load calculation and module sizing for the proposed LED lamp for all sectors were shows in Table 10 and Fig. 9.

Anatomy and sizing of the eastern plant: The total energy needed from the plant is $164 \mathrm{Kwh}$ that amount of energy need about 476 modules to meet the consumption, we should calculate the number of modules in series and parallel for area and layout of the plant.

The calculation for the eastern sector with $250 \mathrm{w}$ mercury tubular is 1262 lamps. Table 9 shows the calculation for the anatomy with LEDs lamps the total consumption per hour (164 Kwh) and number of module (476), note that we approximate the total number of modules to an even number.

The change in total energy need to run the lighting system has an effect on the storage system (batteries) type, specification, number of batteries and construction anatomy (number of batteries in series and batteries in parallel). The results of batteries, modules anatomy and CR are show in Table 11. 


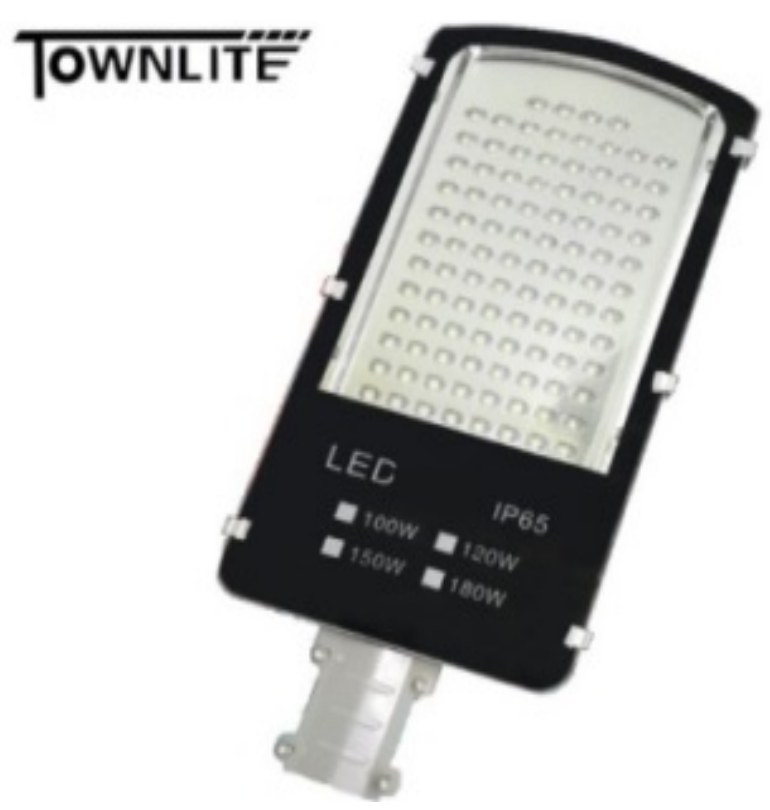

Fig. 8: LED lamp

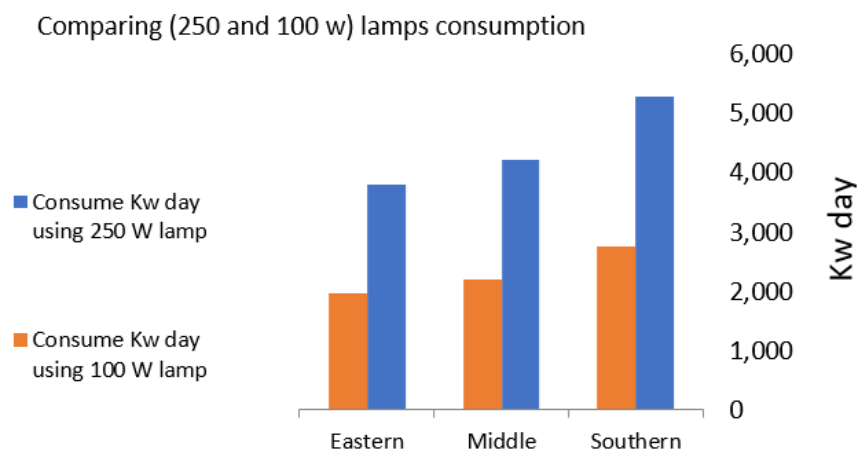

Fig. 9: Comparison load data for all sectors

Table 10: Sector load and module data

\begin{tabular}{llllll}
\hline Sector & No. of lamp & Consume/Kw h & Factor $1.3 \mathrm{Kw} \mathrm{h}$ & Consume/Kw day & No. of module \\
\hline Eastern & 1,262 & 126.2 & 164.45 & 1,973 & 476 \\
Middle & 1,400 & 140.0 & 182.00 & 2,184 & 528 \\
Southern & 1,760 & 176.0 & 228.90 & 2,747 & 664 \\
Total & 4,422 & 442.2 & 576.29 & 6,807 & 1,668 \\
\hline \multicolumn{7}{l}{} \\
\multicolumn{7}{l}{ Table 11: The eastern sector basic items quantities } & & & \\
\hline Type & Series & Parallel & Quantity & Given & Need \\
\hline Modules & 4 & 120 & 480 & $165.60 \mathrm{Kwh}$ & $164 \mathrm{Kwh}$ \\
Batteries & 12 & 28 & 312 & $209.60 \mathrm{Kw}$ day & $1968 \mathrm{Kw}$ day \\
CR & - & 64 & 64 & 12.200 amps & $12.190 \mathrm{amps}$ \\
\hline
\end{tabular}

Modern street light system: All-in-one system is a unit, which contains all items of solar lighting system (LED lamp, battery, wires...act); it's an off-Grid system (standalone).

It has high burning hours, low power consumptions, high efficiency and absolutely no battery maintenance required for at least 3 to 4 years. Figure $10 \mathrm{a}$ and $10 \mathrm{~b}$ show the items and structure of all in one system, which contains of mono-crystalline panel and controller linking it with lithium ion battery and a motion sensor, with others structure such as case with water proof and unit stand (Anand and Jain, 2015).

The proposed of all-in-one system: The selected allin-one units match Port Sudan street lighting requirement and specification of pole height and distance. This unit has a 15,000 $\mathrm{lm}$ and 50,000 burning hours and water proof case with 80 USD price also with no maintenance for the 3 first years, as shown in Fig. 11. 


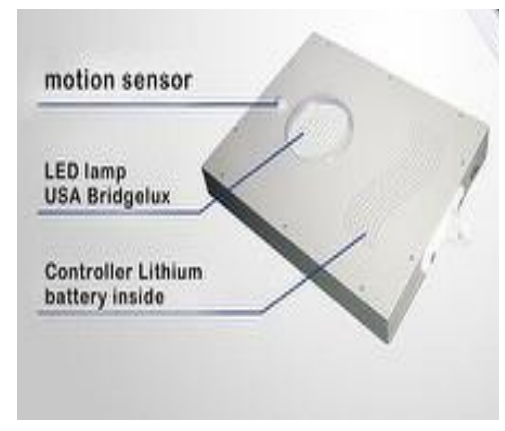

(a)

Fig. 10: The structure of all in one system

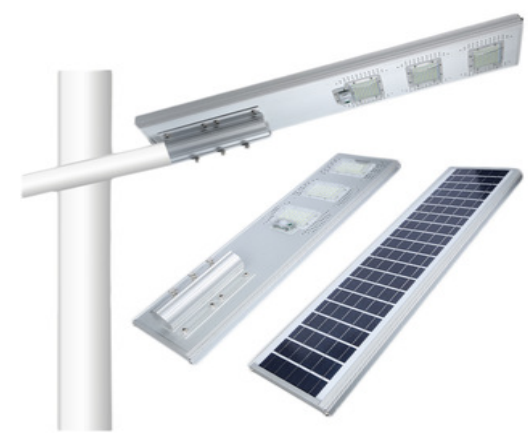

Fig. 11: The proposed all in one unit

\begin{tabular}{|c|c|c|c|}
\hline Sector & & $\begin{array}{l}\text { Quantity } \\
\text { needed }\end{array}$ & $\begin{array}{l}\text { Price by } \\
\text { USD }\end{array}$ \\
\hline Plant with 250 Watt & AC lamp & & \\
\hline \multicolumn{2}{|l|}{ Eastern } & 1,262 & 100,960 \\
\hline \multicolumn{2}{|l|}{ Middle } & 1,400 & 112,000 \\
\hline \multicolumn{2}{|l|}{ Southern } & 1,760 & 140,800 \\
\hline \multicolumn{2}{|l|}{ Total } & 4,422 & 353,760 \\
\hline \multicolumn{4}{|c|}{ Plant with 250 Watt LED lamp } \\
\hline \multicolumn{2}{|l|}{ Eastern } & 1,262 & 25,240 \\
\hline \multicolumn{2}{|l|}{ Middle } & 1,400 & 28,000 \\
\hline \multicolumn{2}{|l|}{ Southern } & 1,760 & 35,200 \\
\hline \multicolumn{2}{|c|}{ Total } & 4,422 & 88,400 \\
\hline \multicolumn{4}{|c|}{ All in one (one system) } \\
\hline \multicolumn{2}{|c|}{ Eastern } & 1,262 & 100,960 \\
\hline \multicolumn{2}{|l|}{ Middle } & 1,400 & 112,000 \\
\hline \multicolumn{2}{|l|}{ Southern } & 1,760 & 140,800 \\
\hline \multicolumn{2}{|l|}{ Total } & 4,422 & 353,760 \\
\hline
\end{tabular}

Table 12 shows the quantities of lamps needed and price by USD for each type of plant, in spite of the third type (all in one) is a complete system (panel and battery and charge control. We will compare between the three systems. The results shown the same total price for the two type (plant with $250 \mathrm{w}$ lamps and All in one type) because the single price for the $250 \mathrm{w}$ the street light use now is the same price for the proposed all in one system (80\$).

Technical filtrations: To filter the three types we should put some standards to select the best type, after the pre-study (economic and technical) base on the

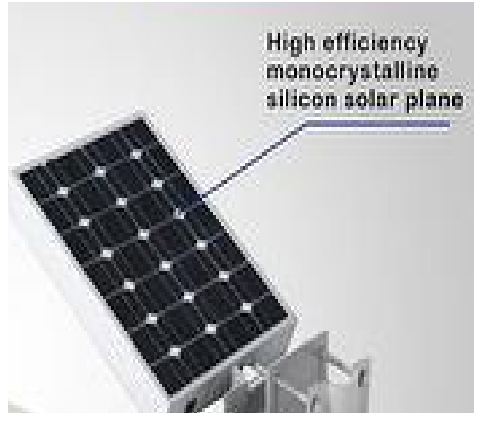

(b)

technical data sheets from the companies. The plant with $250 \mathrm{w}$ AC lamps needs an inverter as we mentioned these inverters within the Balance of System (BOS) among with cabins and condition system and control system with other auxiliaries etc. The (BOS) takes rise up the total to (60-70\%) of the solar off-grid storage systems, also increase maintains cost and the technical cost (installation and mounting and service) of the plant. The LED lamps consume 0.4 times than the $250 \mathrm{w}$ lamps, with no need to investors that means less maintains and mounting also less (BOS) percentage cost $(<60 \%)$, on the other side the All in one system more applicable and less technical support cost with easy installation cost.

\section{CONCLUSION}

Port Sudan city as capital for the red sea state and as touristic city consumes a large power for street light. The government of the state insures this power from the state treasury daily by feeding the electrometers to supply every group of pole lamp in the city streets. It cost about (3,390,996 SUP) yearly from the state treasury. The power supplied to operate the net of the street light is taken from the city share of power granted from the National Electricity Corporation (NEC). In the summer the consumption rises and the peak load get higher than the power granted. The streetlight system must be working from (6 pm to $6 \mathrm{am})$. The modern cities tend to reduce the power consumption for the community load such as street light and traffic light, traffic signal by supplying the power to them from renewable energy (especially solar). In this study we tried to select between three of solar power plant. The first option depends on using the old light system components such as the type of lamp used $(250 \mathrm{w}$ AC nominal power with 28,000 burning hours) and the same wires connections and calculated the load and PV solar sizing need to suit that consumption of energy during $12 \mathrm{~h}$ of operation. The calculations were very costly about (29 USD/watt) and 31 million American 
dollars initial cost, because the high power consumed by the lamp and the converting process from DC current of the panels to AC current of the used lamps, so it's not practical and economical also. The lamps are major factor in the sensitivity analysis, because of their high nominal power. We proposed to change the lamps type with another type which has less nominal power and gives applicable specification to meet the street and poles design specification (pole height, distances between two poles) and also give appropriate illumines according to national specifications. We changed lamps by LED lamps with $100 \mathrm{~W}$ and much higher burning life $(50,000 \mathrm{~h})$. The calculations have shown reduced energy consumption by $60 \%$ than the first proposed plant and less initial cost, because no need for an inverter and their additional equipment with 12 million American dollar which is $60 \%$ less than the first proposed plant. With those two proposed systems to transform Port Sudan lighting system to solar lighting system with high initial cost. The proposed system chosen is called (All in one) street lighting system, this system is more applicable, no need highly trained workers, easy to construct, with minimum maintenance and long burning period $(50,000 \mathrm{~h})$ about 11.5 years operation. The proposed system cost about 398,090 SUP which can be restore by the government in 5 years after construction and saving about 428,000 USD $(21,391,500$ SUP) in the next 6 years. Developing of All in one system with LED lamps that suite a situation in street lighting system is extremely important. Government and research and academic institutions can play a role to provide these all in one with LED lamps as street lighting system. Research in the field of renewable energy technology in Sudan must be encouraged.

\section{REFERENCES}

Abdel Ati, H., 2000. Internally Displaced People (IDPs) in Port Sudan Town, Red Sea State. A Report for Ockenden International, Sudan, November.

Aghaei, P. and P. Meisen, 2014. Solar Electric and Solar Thermal Energy: A Summary of Current Technologies. Global Energy Network Institute, November 2014, pp: 1-40.

Amogpai, A., 2007. Lighting and energy usage in Sudan. M.A. Thesis, Helsinki University of Technology, Espoo, Finland.

Anand, S. and N. Jain, 2015. Intelligent street light system using wireless Transmission: A review. Int. J. Adv. Res. Electron. Commun. Eng., 4(2).
Bajpai, P., V. Das and N.K. Kishore, 2010. Bi-annual sun tracking for solar PV module support structure: Study and implementation. Proceeding of 16th National Power Systems Conference, Dec. 15th17th, 2010.

Boyce, P.R., S. Fotios and M. Richards, 2009. Road lighting and energy saving. Light. Res. Technol., 41: 245-260.

Christian, D. and P. Lestari, 2017. Lighting Technique and Lighting Layout. Artolite Grasindo. Basic Theory of Public Street Lighting Accessed Retrieved April 27, 2017.

Doughty, D.H. and E.P. Roth, 2012. A general discussion of Li Ion battery safety. Electrochem. Soc. Interface, 21(2): 37-44.

EIA (US Energy Information Admin.), 2016. International Energy Outlook 2016. Department of Energy (DoE), Washington, DC, USA, May, 2016.

El Mamoney, M.H. and A.E.M. Khater, 2004. Environmental characterization and radioecological impacts of non-nuclear industries on the Red Sea coast. J. Environ. Radioactiv., 73(2): 151-168.

Fujii, Y., N. Yoshiura, A. Takita and N. Ohta, 2013. Smart street light system with energy saving function based on the sensor network. Proceeding of the 4th International Conference on Future Energy Systems, pp: 271-272.

IEA (International Energy Agency), 2003. Renewable for Power Generation: Status and Prospects. 2003 Edn., OECD, Paris, France.

Karekezi, S. and W. Kithyoma, 2003. Operationalizing the NEPAD Energy Initiative. Renewable Energy in Africa. Novotel, Dakar, Senegal, June 2-4, 2003.

Kumar, B.S. and K. Sudhakar, 2015. Performance evaluation of $10 \mathrm{MW}$ grid connected solar photovoltaic power plant in India. Energ. Reports, 1: $184-192$.

NEC, 2014. National Electricity Corporation, Khartoum, Sudan, Executive Summary for Year 2014.

Omer, A.M., 2002. Overview of renewable energy sources in the Republic of the Sudan. Energy, 27: 523-547.

Omer, A.M., 2005. Biomass energy potential and future prospect in Sudan. Renew. Sust. Energ. Rev., 9(1): $1-27$.

Panjang, R. and B. Ulu, 2015. Off-grid Solar PV Lighting Project System Sizing and Yield Analysis. Revision 1.1, February, 2015. 